\title{
MERCHANT IDENTITY AND CARTOGRAPHIC IMPULSE IN THE ARCHITECTURAL SCULPTURE OF THE LONJA OF PALMA DE MALLORCA
}

\section{DORON BAUER}

UDC: $725.2(460.32) " 14 "$ $72.04(460.32) " 14 "$

Review

Manuscript received: 17. 08. 2015.

Revised manuscript accepted: 15. 03. 2016.

DOI: 10.1484/J.HAM.5.111355
D. Bauer

The Florida State University

Department of Art History 1019 William Johnston Building 143 Honors Way

Tallahassee, FL 32306 - 1233, USA

The Lonja of Palma de Mallorca served as the seat of the College of Merchants as well as a stock exchange mainly for merchants engaged in maritime trade. Construction was carried out throughout the first half of the fifteenth century under the supervision of the architect Guillem Sagrera. The contract signed between Sagrera and the Merchant Guild has survived and allows us a better understanding not only of the merchants' practical goals in building the Lonja but also their symbolical ones. The paper will demonstrate how the Lonja's architectural sculpture transgressed its pure iconographical function and used to point to urban landmarks important to the merchants. By doing so the merchants generated an imaginary map that formed only a slice of the city's geographic reality. The merchants did so in order to assert ownership and make territorial claims in light of tensed and conflictual political climate.

Keywords: Lonja of Palma de Mallorca; Cartography; Merchant Guild; Gothic Sculpture

The Lonja of Palma de Mallorca is a late medieval building built in the gothic style (fig. 1). Lonja in Spanish means "exchange", and as its name suggests, the Lonja served as a stock exchange mainly for merchants engaged in maritime trade. Construction was carried out throughout the first half of the fifteenth century under the supervision of the architect Guillem Sagrera. The Lonja's importance lies in the fact that it set new standards for Mediterranean trade architecture in terms of its design and aesthetics and consequently different aspects of the building were copied and appropriated. The Lonja of Valencia, built between 1482 and the middle of the sixteenth century, serves as a conspicuous example as it clearly attempts to imitate the Lonja of Palma. ${ }^{1}$ The patron of the Lonja of Palma was the Colegio de Mercaderes or the local merchant guild. ${ }^{2}$ In 1409, the merchants of Palma petitioned to Martin the Humane,

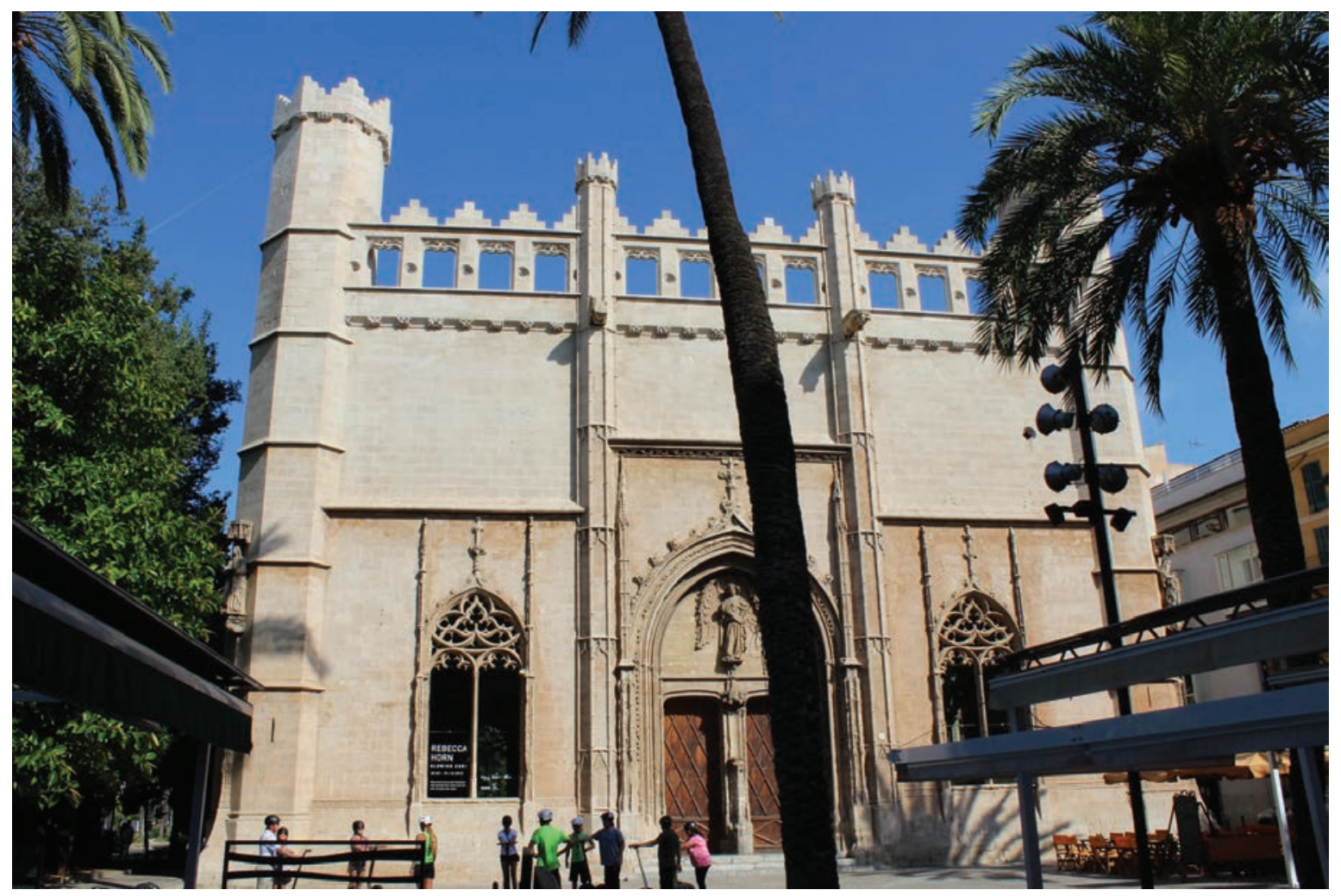

Fig. 1. The Lonja of Palma

${ }^{1}$ S. ALDANA FERNÁNDEZ, La Lonja de Valencia, Valencia, 1988.

${ }^{2}$ R. S. SMITH, The Spanish Guild Merchant; a History of the Consulado, 1250-1700, New York, 1972. 


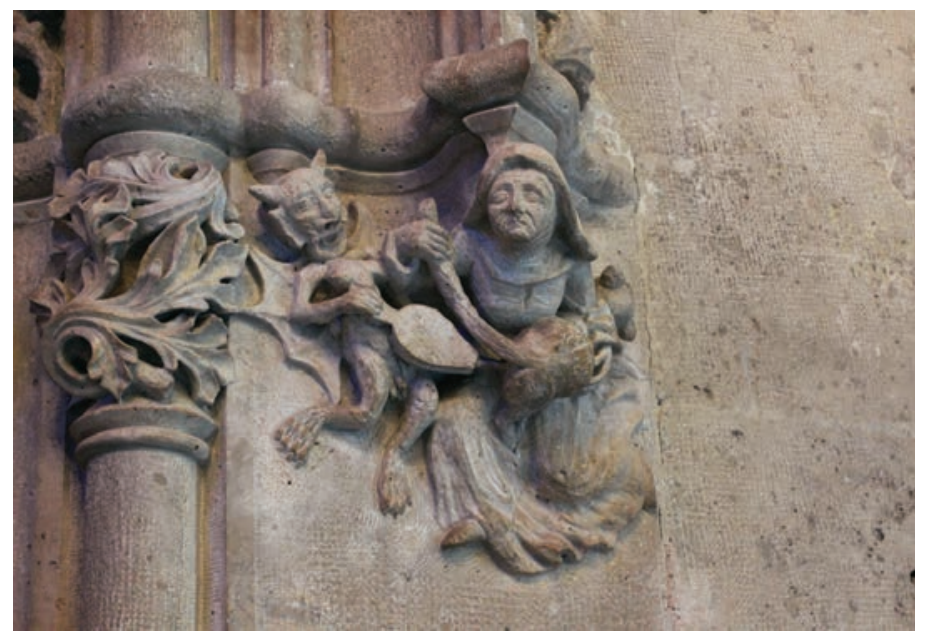

Fig. 2. Profane sculptural decoration, The Lonja of Valencia

King of Aragon, asking his permission "to build a Lonja that will ennoble the merchant profession and the whole city."3 Due to the identity of its patron and its innovative character, the Lonja provides a rare opportunity to examine the manner in which architecture of trade expresses, or better put, negotiates, the identity or self-perception of the fifteenthcentury merchant class.

The departure point of this paper is the tension engendered between a widely spread modern conception regarding the merchant class and an observation made by a sixteenthcentury Emperor. In the eyes of many prominent historiographical studies, fifteenth-century merchants are cast as the forerunners and "heroes of self-centered modernity," humanism and individualism. ${ }^{4}$ The rise of the merchantclass, among other things, marks the birth of free individual spirit and the beginning of a long trajectory leading away from the alleged rigid religiosity and conformity of the Middle Ages. Such a view may find justification in the sculptural decoration of some late medieval or early modern buildings associated with merchants. The Bourges palace of Jacques Coeur - a fifteenth-century prominent and wealthy French merchant - features motifs alluding to Jacques' trade with North Africa and the Levant, including among other things, a magnificent ship, monkey and negroids. And in the Lonja of Valencia, profane motifs, many of them focus on buttocks, no less, are profuse (fig. 2).

However, the Lonja of Palma is different. To understand its difference it is perhaps best look at the Lonja through the eyes of the Holy Roman Emperor Charles V. In 1541, Charles set sail to capture the city of Algiers from the Ottomans.
On its way to North Africa, the fleet anchored in the bay of Palma and the Emperor visited the city:

So on entering the city and moving from the plaça del moll to the plaça de Lonja he saw many people in the streets and in the windows and still on the housetops and roofs, that as a sign of the great content he appears to have from so many people and from the place he turns and leads the horse around all parts [of the stretch between the Moll and the Lonja], to see and be seen by all. And walking to the entrance of [or around] the Lonja examining the purpose of the building, he asked if it was a church. ${ }^{5}$

For the well-traveled and well-educated emperor, then, the Lonja seemed like a church. The church-like appearance of an important building commissioned by the merchant guild contrasts with the view of merchants as a driving force of "secularism". I would like to show that this contradiction could be reconciled by carefully examining the Lonja's architectural sculpture.

\section{THE CORNERS SCULPTURES}

One of the items listed in the contract signed between the merchant guild and Guillem Sagrera in 1426 is concerned with the sculptural decoration of the new building: 6

Also, that the said Guillem is required to make in each of the four corners of the said Lonja, a great figure, each one in its own tabernacle which corresponds to the other tabernacles of the angels; that is, the one on the corner that watches over the port of Portupi, St. Nicholas; and on the corner that watches over the church of St. John, St. John the Baptist; and on the corner that watches over the Darasana, St. Catherine; on the corner that watches over the said Castell Reyal, St. Clare. ${ }^{7}$

Why the merchant guild made these particular iconographic choices? Why St. Nicholas, St. John, St. Catherine and St. Clare, and not other religious or secular figures? The key to the answer lies in the wording of the contract itself. The merchants took care to state the position of each sculpture in relation to a particular landmark. By doing so, the merchants linked each statue with a landmark by means of imaginary vectors. I will now examine the rationale underlying each link in more detail.

St. John

The most evident connection, as well as physically the shortest vector, is the one between the statue of St. John the Baptist (fig. 3) and the church of St. John the Baptist (red vec-

\footnotetext{
3 G. ALOMAR ESTEVE, Guillem Sagrera y la arquitectura gótica del siglo XV, Barcelona, 1970, p. 117.

${ }^{4}$ G. TODESCHINI, Theological Roots of the Medieval/Modern Merchants'Self-Representation," in M. C. JACOB and C. SECRETAN (eds.), The Self-Perception of Early Modern Capitalists, New York, 2008, p. 17-46.

5 "De modo que entrant en ciutat y discorrent de la plaça del moll fins a la plaça de Lonja veya tanta gent per les carreras y finestras, y encara per los terrats y teuladas, que en senyal de la gran contentacio que mostra tenir de tans pobles y del loch se gira y volta lo cauall per totas parts, per veure y esser vist de tots. Y acaminant a la volta de Lonja veent lo objecte del edifici de aquella, demana si era yglesia." In J. ODÓN GOMIS, Libre de la benaventurada vinguda del Emperador y Rey don Carlos en la sua ciutat d'Mallorque y del recebiment que li fonch fet, Palma de Mallorca, 1973, p. 15.

${ }^{6}$ On the sculptural program of the Lonja, see T. SABATER, El programa escultórico, in F. CLIMENT GUIMERÁ, C. CANTARELLAS CAMPS, and J. VELLÉS (eds.), La Lonja de Palma, Palma de Mallorca, 2003, p. 107-25.

7 "Item, que lo dit Guillerm dege é sia tengut fer en quascun dels quatre cantons de la dita Lotge de par de fore, una gran figura, quescuna en son Tabernacla corresponent als alters Tabernaclas dels Angells, ço es en lo cantó que sesgarda vers lo port de Portupi, San Nicolau; é en lo cantó qui sesgarda vers la Iglesia de Sant Juan, Sant Juan Bautista; è en lo cantó qui sesgarda vers la Darasana, Santa Catalina; en lo cantó qui sesgarda vers lo dit Castell Reyal, Santa Clara." In D. A. FRAU, La Lonja de Palma. Documentos, in Bolletí de la Societat Arqueològica Lulliana 1, no. 22, 1885, p. 4-5; Idem, La Lonja de Palma, in Bolletí de la Societat Arqueològica Lulliana 1, no. 14, 1885, p. 2; G. ALOMAR ESTEVE, op. cit. (n. 3), p. 124.
} 


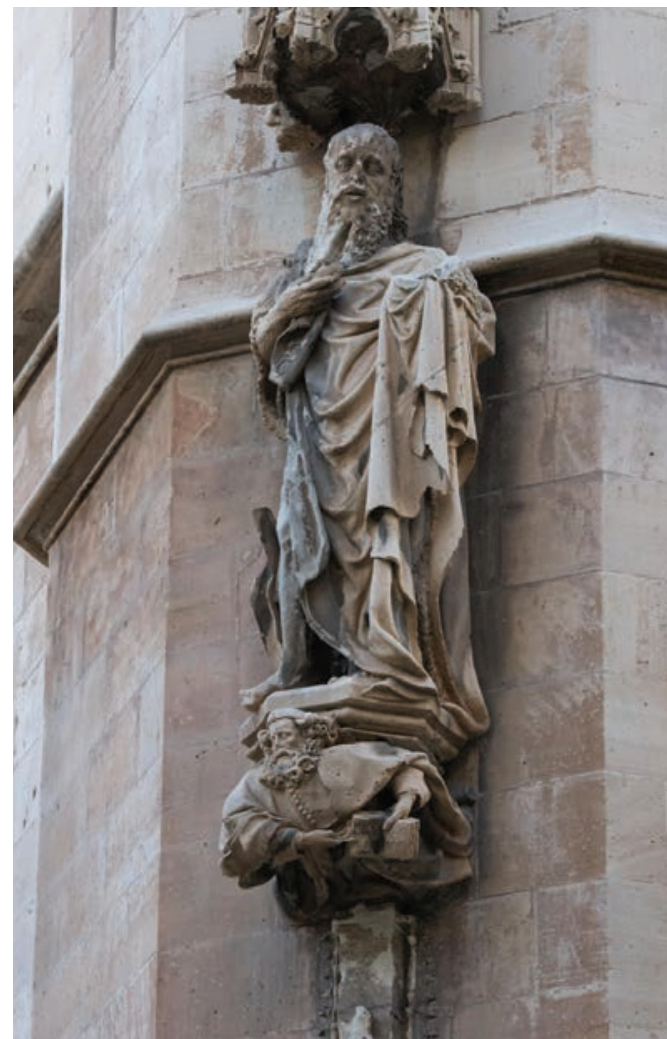

Fig. 3. St. John the Baptist, The Lonja of Palma

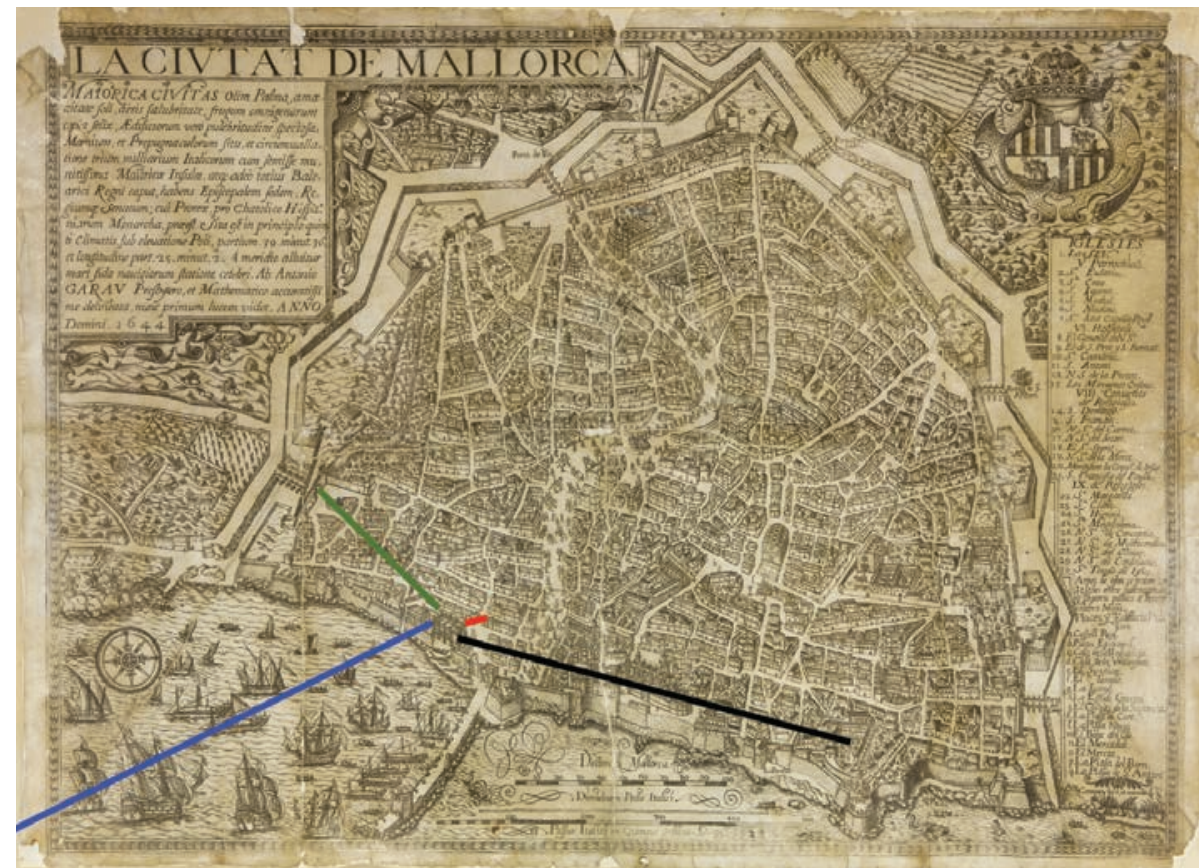

Fig. 4. Antonio Garau's 1644 map of Palma de Mallorca, Biblioteca Bartolomé March (Photo: La Fundación Bartolomé March)

tor on fig. 4). The church of St. John was associated with the Knights Hospitaller, frequently referred to in the fifteenth century as the Knights of Rhodes. The church, which gave its name to the eponymous city gate facing the "moll" (the pier), is located across the street, east to the Lonja. The Hospitaller church of St. John the Baptist served as the meeting place of the guild before the construction of the Lonja, hence its importance to the merchants. ${ }^{8}$

\section{St. Nicholas}

Of the four corner statues, the statue of St. Nicholas is the only one that did not survive. It was mysteriously stolen in the nineteenth century and shipped to Genoa by a boat, its traces lost. ${ }^{9}$ The contract states that St. Nicholas should be placed at the corner facing the Portopí. The significance of the Portopí to the merchants of Palma is exemplified by one of the more famous painting from Majorca, the retable of Sant Jordi by Pere Niçard (fig. 5) which was painted around 1470 not too long after the Lonja was already standing. ${ }^{10}$ The retable shows at the foreground St. George killing the dragon. Behind them, an unidentified noble damsel watches the scene. Further to the back, a port city is portrayed. This portrayal is of significant historical value since it provides a rare and relatively accurate representation of the bay of Palma and its port in the fifteenth century even though Pere Niçard applied the Flemish style, in which he was versed, to the depiction of the Mediterranean city. Protruding into the bay, right beneath a windmill, one can see a low fortified structure. The road between this low tower and the city gate is busy with people going out of and into the

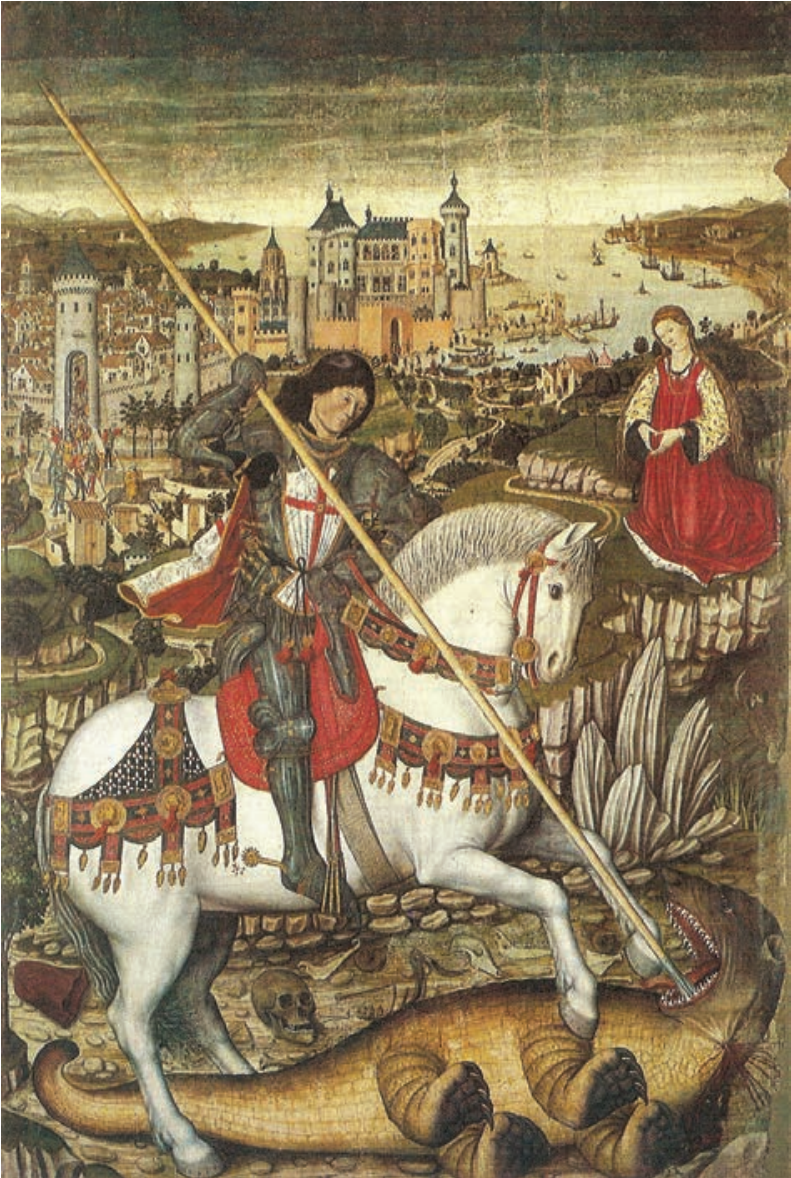

Fig. 5. Sant Jordi Retable by Pere Nicard, Museo diocesano de Mallorca

city. This is most probably the "moll", or the pier leading to the St. John Gate (compare with the low tower on the pier in Antonio Garau map of 1644, fig.4). The Portopí is shown

${ }^{8}$ G. ALOMAR ESTEVE, op. cit. (n. 3), p. 117. The church was known also as Sant Joan del Mar or Sant Joan de Malta.

9 Ibid., p. 131 and B. FERRÁ, Nuestra lámina, in Bolletí de la Societat Arqueològica Lulliana 1, no. 21 1885, p. 5.

${ }^{10}$ El Cavaller i la princesa: el Sant Jordi de Pere Nisard i la ciutat de Mallorca, Palma de Mallorca, 2001. 


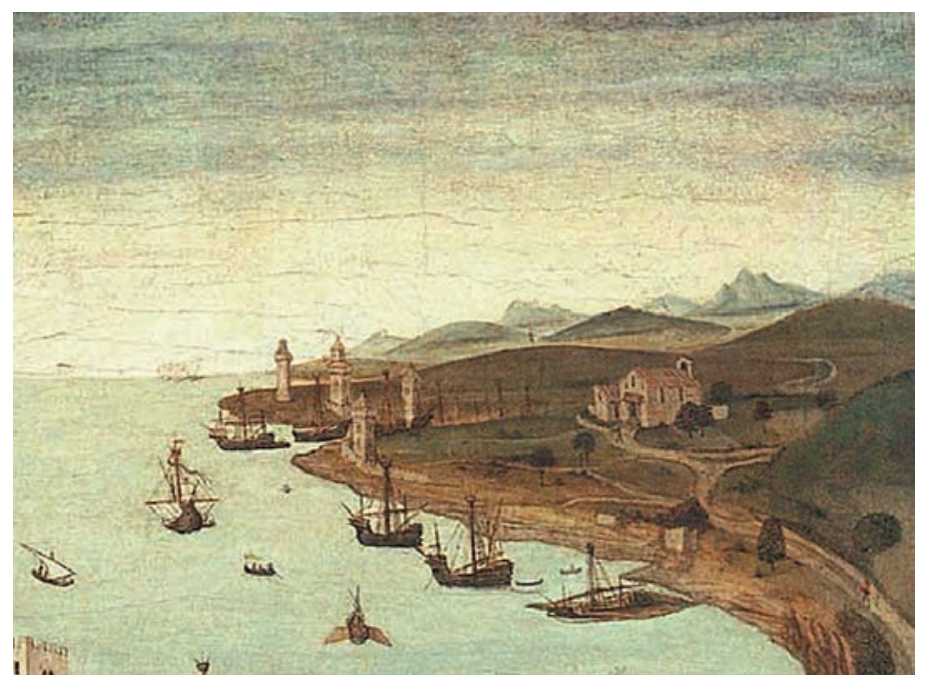

Fig. 6. Sant Jordi Retable (detail)

on the upper right side of the painting as an inlet enclosed by four towers (fig. 6). The bigger ships are concentrated in the area of the Portopí while smaller boats are shown in the vicinity of walled city. The fact that most of the big merchant ships anchored in its area demonstrates that the Portopí was the major port of Palma." Palma's port authority, the guardinant del port, ordered ships to withdraw to the Portopí because there ships could have been sheltered and protected by means of defensive towers and a boom. It is no surprise then that the merchant guild wanted to "connect" its newly built headquarters - the Lonja - with the port - the center of maritime trade (blue vector on fig. 4 indicates the general direction of the Portopí, however the Portopí itself is not included in Garau's map).

The merchant guild chose St. Nicholas to mediate this connection because St. Nicholas is the patron saint of sailors and merchants. For example, in one of the miracle stories attributed to saint in the Golden Legend, sailors pray to St. Nicholas at time of turmoil:

One day some seamen, threatened by a violent storm at sea, shed tears and prayed as follows: "Nicholas, servant of God, if what we have heard about you is true, let us experience your help now."12

Moreover, In Pere Niçard's Sant Jordi, the building adjacent to the four towers of Portopí is a church that served the seamen, merchants and port workers. The church, which was destroyed in the nineteenth century, was dedicated to St. Nicholas, and was called Sant Nicolauet Vell de Portopí to differentiate it from the church of St. Nicholas within the city walls.

The statue of St. Nicholas, then, substantiated the imaginary vector between the Lonja and Palma's major port by means of its position on the western corner of the building facing the Portopí; the fact of St. Nicholas being the patron saint of merchants and sailors; and also by hinting to the Saint's church at the port. ${ }^{13}$

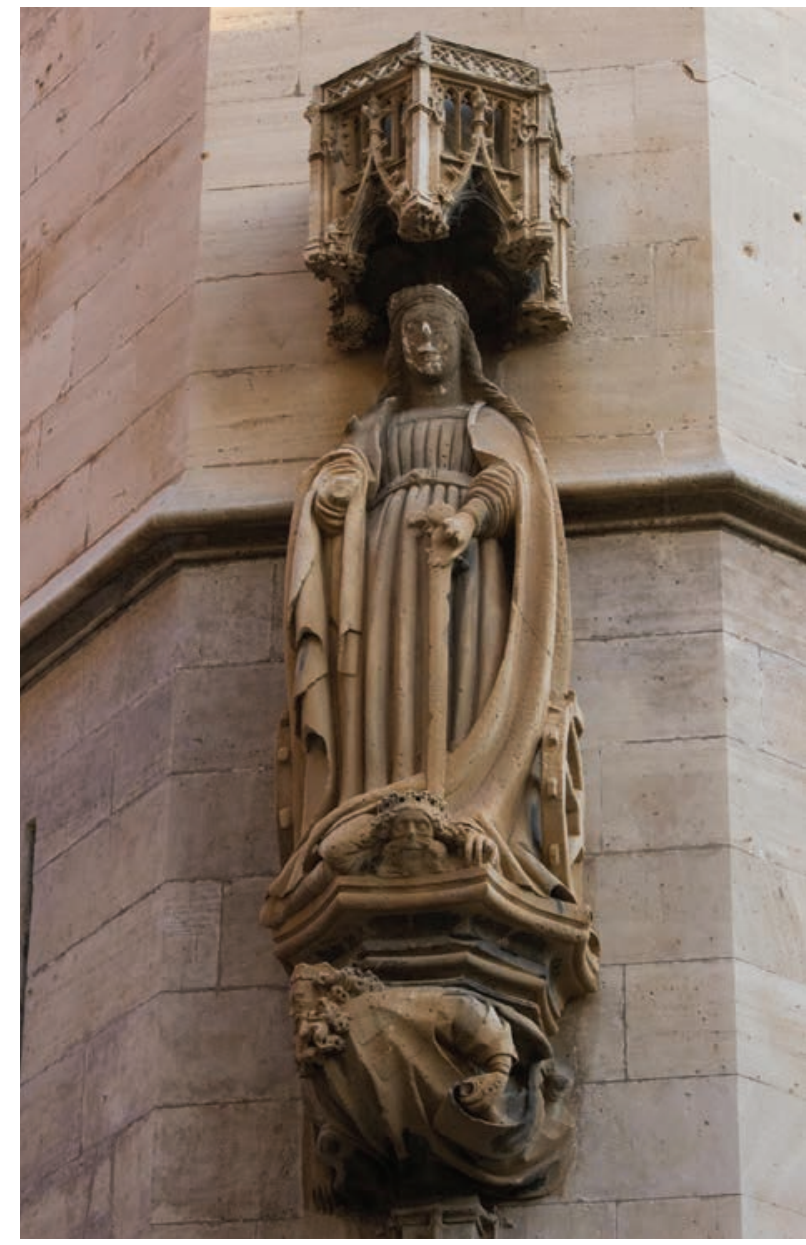

Fig. 7. St. Catherine, The Lonja of Palma

\section{St. Catherine}

The statue of St. Catherine (fig. 7) was placed at the corner that, according to the contract, watches over the Drassana. The Drassana in Catalan is a ship- or boatyard and indeed the square bearing that name, about 200 feet northwest of the Lonja, served as such. A shipyard is of course directly related to trade and mercantile interests. However, to judge by the square's relatively small size and by the square's depiction in the map of Antonio Garau, the Drassana in Palma was intended for small boats rather than for the bigger merchant ships. In addition, there is apparently nothing in the Drassana to connect it with St. Catherine. And as we saw in the two previous cases - that of St. John the Baptist and that of St. Nicholas - the statues were intended to point toward structures bearing the saints' name. The city gate of St. Catherine is located a little bit further to the northwest of the Drassana. The gate marked the start of the main road connecting the city and the major port - the Portopí. Furthermore, following a vow he made during a shipwreck, a wealthy merchant named Ramon de Salelles founded in 1343 the Hospital of Santa Catalina dels Pobres outside the city walls next to the road leading to the Portopí. The hospital's primary function was to serve poor sailors. ${ }^{14}$ Therefore, the statue of St. Catherine

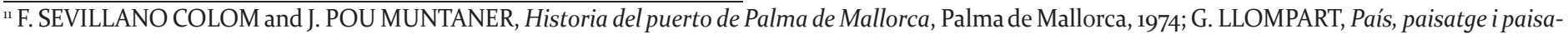
natge a la taula de Sant Jordi de Pere Niçard, in El Cavaller i la princesa: el Sant Jordi de Pere Nisard i la ciutat de Mallorca, Palma de Mallorca, 2001, p. 63-4.

${ }^{12}$ J. DE VORAGINE, The Golden Legend: Readings on the Saints, Princeton, 1993, I, p. 22.

${ }^{13}$ Interestingly, in the thirteenth century, a Majorcan merchant ship named after St. Nicholas was appear frequently in archival records. See R. VOSE, Friars on the Edge: Socio-Economic Networking and the Dominicans of Conquered Mallorca, in T. E. L. CHUBB and E. D. KELLEY (eds.), Mendicants and Merchants in the Medieval Mediterranean, Leiden, 2012, p. 70 n.35, 72.
} 


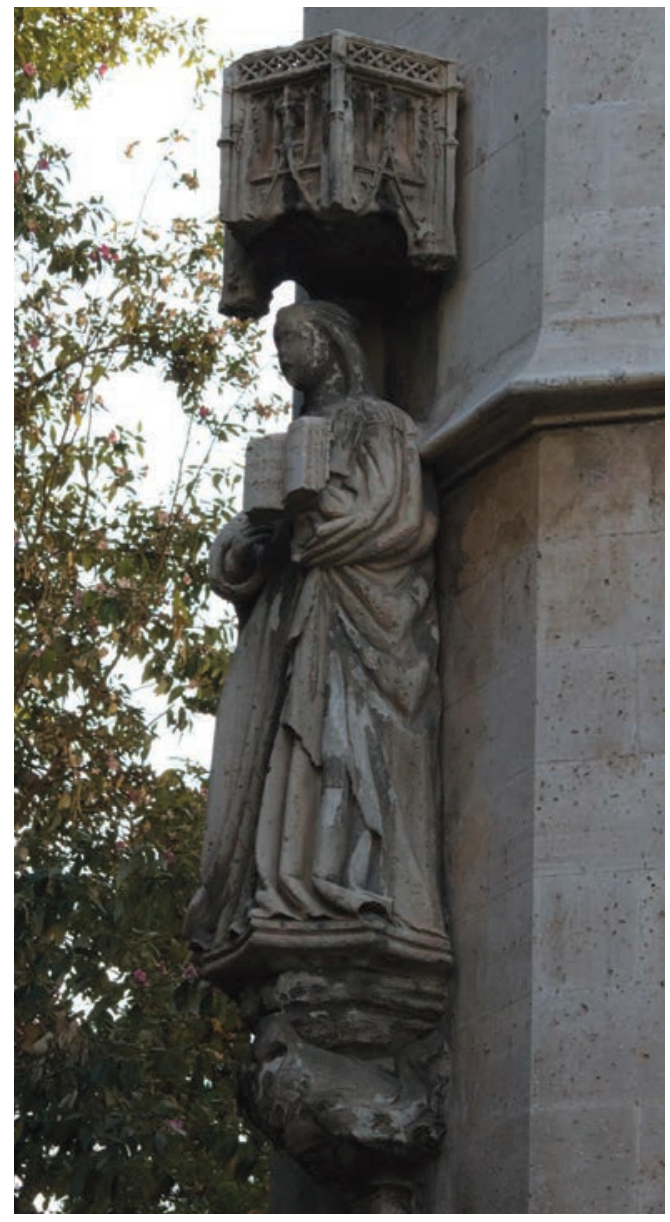

Fig. 8. St. Clare, The Lonja of Palma

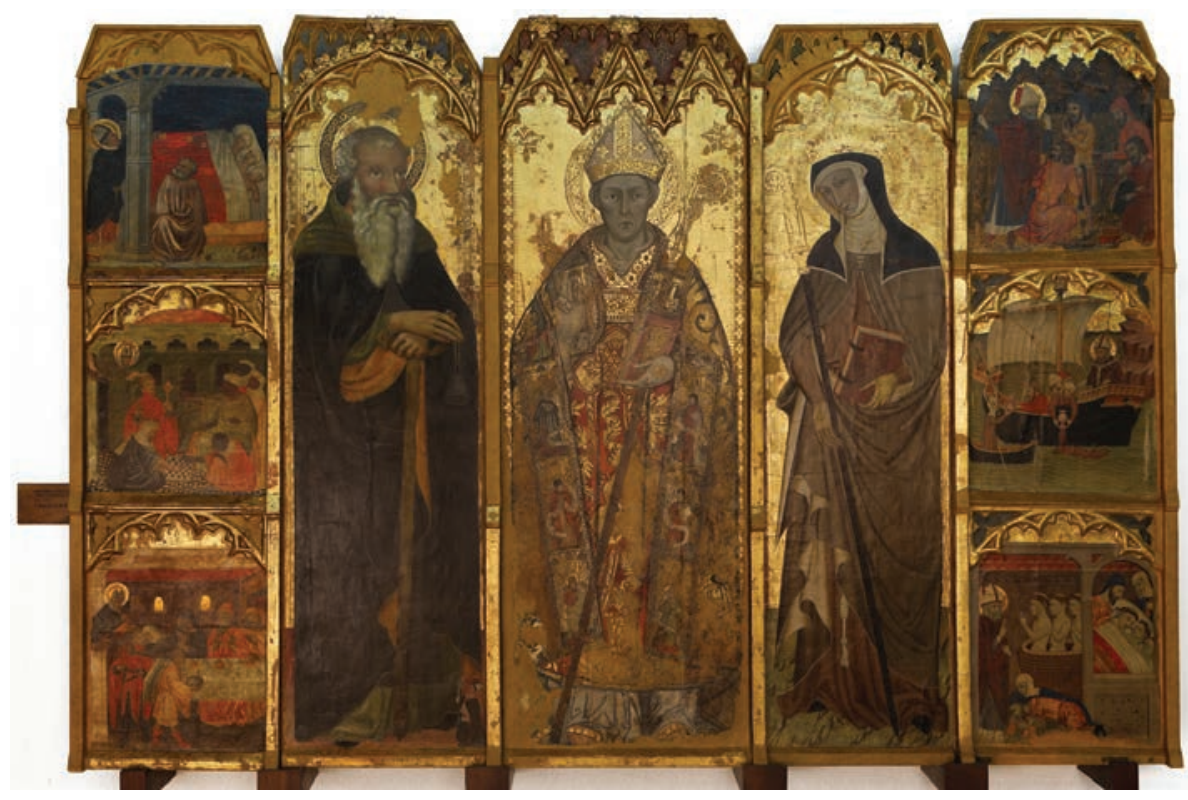

Fig. 9. The Altarpiece of St. Nicholas of Portopi, Museu de Mallorca (NIG DA05/09/011)

most probably meant to point to the gate and to the hospital outside it (green vector on fig. 4).

The choice of St. Catherine was possibly meaningful to Palma's merchants in yet another manner. The Balearics underwent a substantial economic transformation from the late fourteenth century. They became a major wool-producing region and the center of a successful textile industry aimed at the upper middle part of the market. ${ }^{15}$ The building of the Lonja is coextensive with the economic transformation that placed wool and textile at the core of Majorcan mercantile activity. Emperor Maxentius sentenced St. Catherine to death by a spiked wheel that broke as soon as the saint touched it. The wheel became an attribute of St. Catherine and as a result she became the patron saint of craftsmen working with a wheel, spinners among them (a wheel is shown on the side of the Lonja's St. Catherine as well, see fig. 7). It was only natural that the merchants of Palma sought to pay homage to the patron saint of the industry that provided them with a major source of income.

\section{St. Clare}

The saints' statues meant to point to structures bearing their name. However, the language of the contract does not always disclose the structure's identity. Instead, the layout of the statues assumes that a beholder familiar with the Palma's urban setting will be able to realize the statue-structure connection based on the general direction and the identity of the given saint. Such is the case with the statue of Santa Clara (fig. 8) which the contract states should face the "Castell Reyal" or the Almudaina. Nevertheless, the monastery of the Santa Clara is located further to the east of the Lonja in the general direction to which the statue of St. Clare points and the name of the saint and the name of the institution match. ${ }^{16}$ Yet why did the merchants choose to symbolically connect the Lonja and the convent of the Poor Clares?

The altarpiece of the previously mentioned port church of St. Nicholas of Portopí has survived and is now on display at the Museu de Mallorca (fig. 9). The altarpiece shows St. Nicholas at the center with six hagiographic scenes from his life. ${ }^{17}$ To his right, St. Nicholas is flanked by St. Anthony and to his left by St. Clare of Assisi - the founder of the Poor Clares. The depiction of St. Clare next to the patron saint of merchants on an altarpiece from a port church suggests that St. Clare was of special importance to the merchants of Palma.

The Poor Clares in the Crown of Aragon were particular attractive for women with mercantile background. For example, around 1236, two such women - Berenguela of Antich and Guillerma of Poliña - founded the monastery of Santa Clara in Barcelona, (initially dedicated to Sant Antoni).${ }^{18}$ More specifically, we know that at least one prominent merchant was associated with the convent of Santa Clara in Palma at the beginning of the fifteenth century. ${ }^{19}$ Bartolome de Bassis or Bartomeu de Bassers was in 1402 one of six jurats - the highest-ranking representative position in Majorca. In 1416 he was allowed to build a chapel in the church of Santa

\footnotetext{
${ }^{14}$ E. DE KOTSKA AGUILÓ, Fundació y documents relatius al hospital de Sta. Catalina de Pobres, in Bolletí de la Societat Arqueològica Lulliana 10, 1904, p. $365-88$.

${ }^{15}$ D. ABULAFIA, A Mediterranean Emporium: The Catalan Kingdom of Majorca, Cambridge, 1994, p. 216-34, esp. 229.

${ }^{16}$ On the convent of Santa Clara, see J. C. SASTRE I BARCELÓ, Espiritualitat i vida quotidiana al Monestir de Santa Clara: ciutat de Mallorca, segles XIII$X V$, Palma de Mallorca, 2006.

${ }^{17}$ The altarpiece includes one scene that takes place at sea alluding to the saint's role as the patron of seamen. The miracle depicted is that of St. Nicholas Cutting Down Diana's Tree, see J. DE VORAGINE op. cit. (n. 12), I, p. 23.

${ }^{18}$ F. FITA, Fundación y primer periodo del Monasterio de Santa Clara en Barcelona, in Boletín de la Real Academia de la Historia 27, 1895, p. 273-314, 436-89; B. ROEST, Order and Disorder: The Poor Clares Between Foundation and Reform, Leiden, 2013, p. 90.

${ }_{19}^{19}$ A. CAMPANER Y FUERTES, Cronicón mayoricense: noticias y relaciones históricas de Mallorca desde 1229 á 180o, Palma de Mallorca, 1881, p. 198; J. SERRA I BARCELÓ, Un procés per faltes de 1417 i el context de les banderies (Mallorca-Segle XV), in Bolletí de la Societat Arqueològica Lul-liana 61, 2005, p. 17.
} 


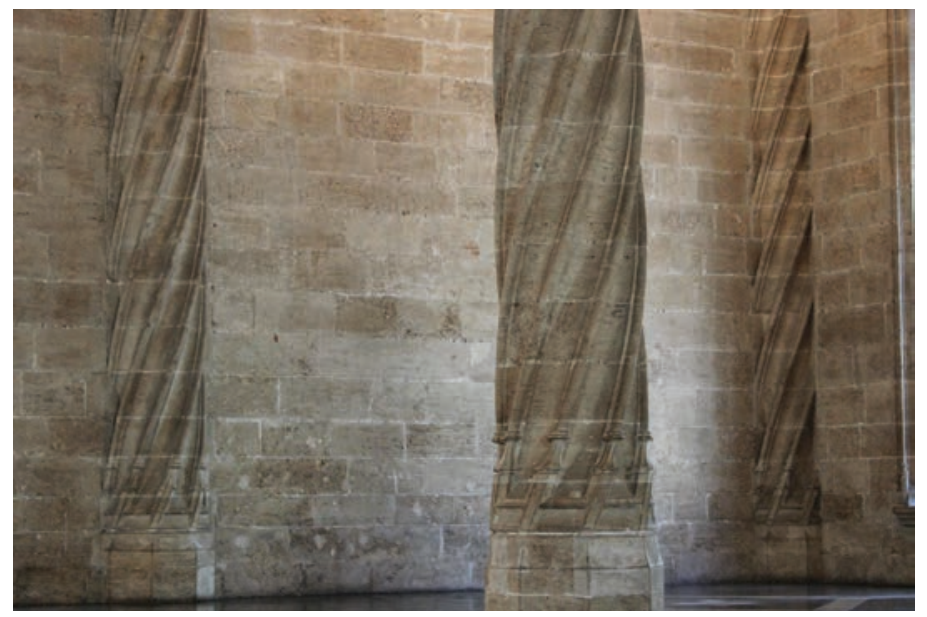

Fig. 11. Twisted Columns, The Lonja of Valencia

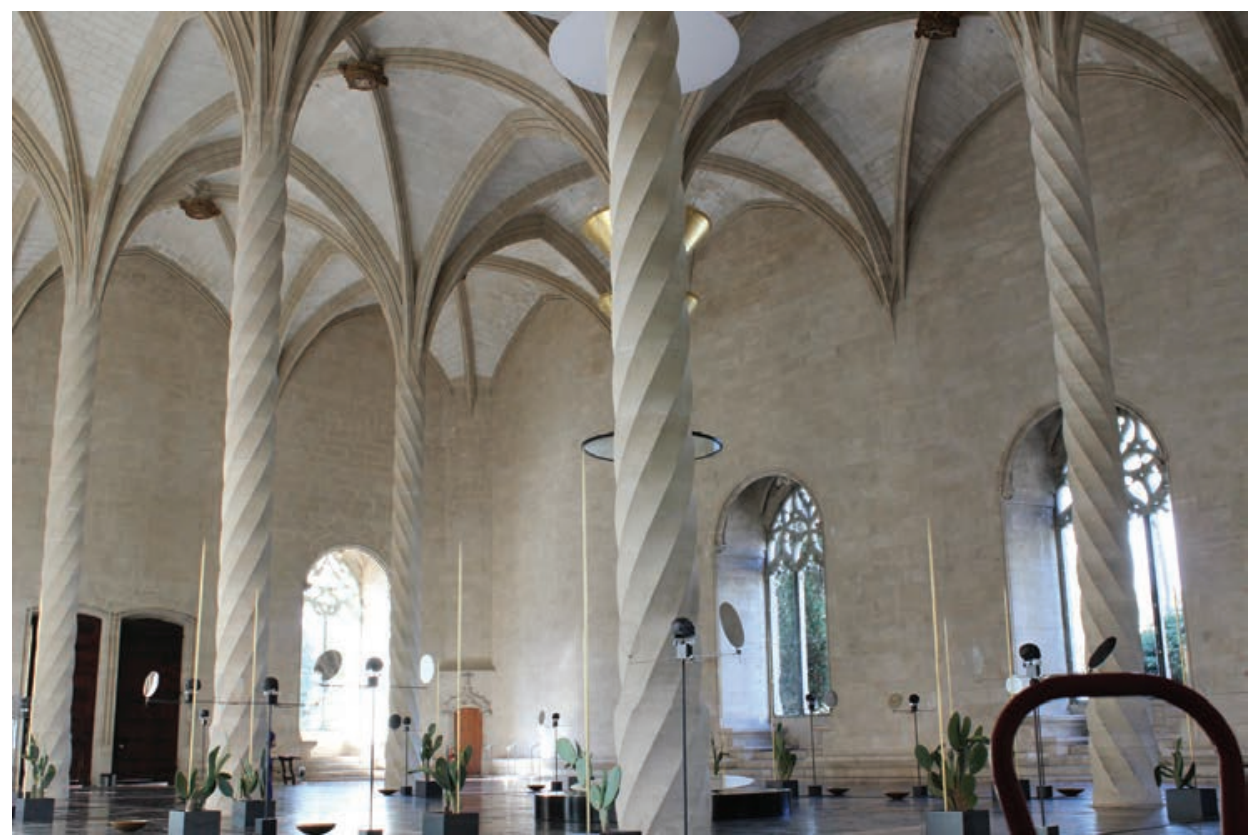

Fig. 10. Twisted Columns, The Lonja of Palma

Clara and inside it a tomb for himself and members of his family. ${ }^{20}$ Sixty nine parchments which document the professional activity of Bartomeu and his eponymous son are now part of the monastery's archive. ${ }^{21}$

The twisted columns supporting the vault cones are one the Lonja's most conspicuous hallmarks (fig. 10). The columns resemble ropes. In the Lonja of Valencia, the columns are even further modeled as ropes showing "strands" exposed towards the base (fig. 11). Ropes were a trademark of ships, and therefore, a sign referring to the merchants' maritime activities. More realistic representations of ropes are carved on a ceiling boss in the Lonja of Valencia (fig. 12) substantiating the validity of such symbolical reading. Not long after their incorporation in the Lonja, the Manueline

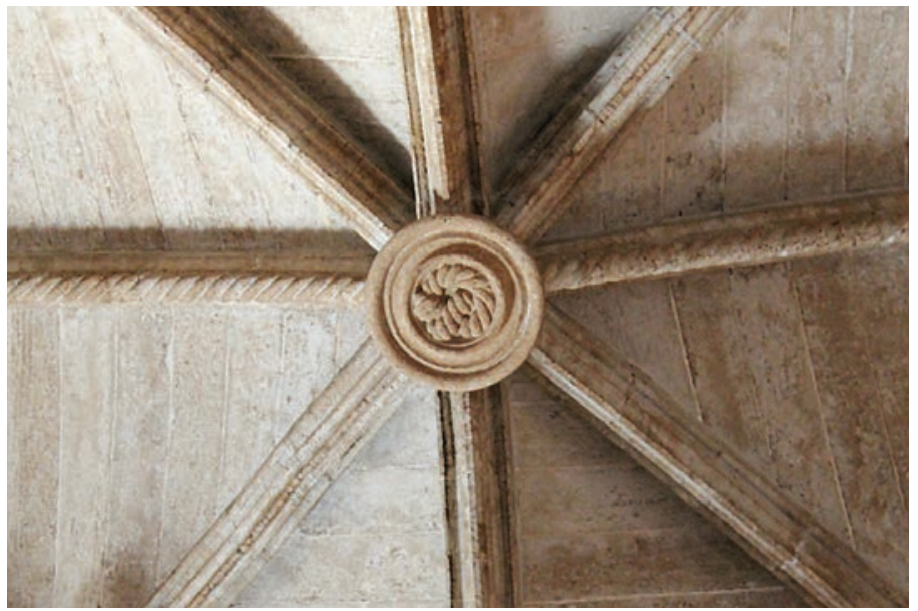

Fig. 12. Boss, The Lonja of Valencia

style made profuse use of carved ropes as an architectural ornament symbolizing maritime activities. The columns may allude also to the importance of the wool industry as they may represent the spinning of fibers. In the Llotja de la Seda (silk) in Valencia, the reference is more explicit since the art of silk production was called l'art de torzedor - the art of twisting.22

Considering the strong association between the Poor Clares and the merchants, the remarkable columns may have carried additional symbolical meaning. The columns do not only represent ropes but they are also vertical. In the Late Medieval imagination, vertical ropes evoked a very common image, that of the Franciscan cord. The Poor Clares wore such cord as well and the cord was one of St. Clare main attributes as can be seen in the corner statue of the saint and in the altarpiece from the church of St. Nicholas of Portopí (figs. 8-9). The Franciscan cord was employed as an architectural element and decorative motif in the late fifteenth-century palace of the Velasco family in Burgos, popularly known as Casa del Cordón (a literal reference to the Franciscan cord embellishing its façade). ${ }^{23}$ Later on, in the sixteenth century, the motif gained popularity in Latin America, as can be seen in the Casa del Cordón, Santo Domingo and the posa chapels of the Convent of San Miguel de Huejotzingo, Mexico. Interesting enough, in the Divine Comedy, the Franciscan cord fluctuates between religious and secular domains. In Canto XVI of the Inferno, Virgil borrows Dante's Franciscan cord "to use as an enormous fishing line for catching the monster Geryon." ${ }^{24}$ The Lonja's

\footnotetext{
${ }^{20}$ L. LLITERAS, Pergaminos del archivo del convento de Santa Clara de Palma, in Bolletí de la Societat Arqueològica Lulliana 16, 1916-17, p. 132-3.

${ }^{21}$ J. C. SASTRE I BARCELÓ, L'arxiu del monestir de Santa Clara: Notes per a la seva catalogació, conservació i difusió, in Bolletí de la Societat Arqueològica Lulliana 48, 1992. p. 284-5.

${ }^{22}$ For Example, E. FAJARNÉS, Fabricacion de sedas y treceopelos en Mallorca (siglos XVI al XVIII), in Bolletí de la Societat Arqueològica Lulliana 22, 1929, p. 193; At least from the 15th century, the authorities made a substantial effort to develop silk industry in Majorca, see M. J. DEYÁ BAUZÁ, Extranjeros en el comercio y la manufactura del Reino de Mallorca en los siglos XVI y XVII, Bolletí de la Societat Arqueològica Lul-liana 62, 2006, p. 43-68.

${ }^{23}$ E. PAULINO MONTERO, El patrocinio arquitectónico de los Velasco (1313-1512). Construcción y contexto de un linaje en la Corona de Castilla, Universidad Complutense de Madrid, 2015.

${ }^{24}$ J. PELIKAN, The Otherworldly World of the Paradiso, in H. BLOOM (ed.), Dante Alighieri, Philadelphia, 2004, p. 171.
} 
twisted columns demonstrate similar fluctuation by referring simultaneously to ships, fibers, and the Clarisses. ${ }^{25}$

\section{THE POLITICAL CONTEXT}

The four corner statues of St. John, St. Nicholas, St. Catherine, and St. Clare transgress their iconographical function and serve as topographical pointers highlighting urban landmarks that held particular value for the merchants. The configuration of the statues is thus site-specific, and more so city-specific, and cannot function in the same fashion in any other place. Such an act of "pointing to" creates a topographical network, circumscribes territories, and as result generates an imaginary map that forms only a slice of the city's geographic reality. It is, therefore, an act that aims at introducing hierarchy into the urban fabric by highlighting certain structures and districts while disregarding others, and by placing the Lonja at the nexus of that imaginary map as its very author. The question is what motivated the merchants to pursue such a strategy of differentiation.

Towards the end of the fourteenth century, the political, social, and economical situation in Majorca became more and more unstable. The events of 1391, most notably the pogrom, accentuated social strife and led to considerable political reconfigurations. ${ }^{26}$ After 1391, the political map was largely divided into two. On the one hand, the Aragonese faction which represented the interests of the aristocracy, and on the other, the Mallorcan faction which was supported by more "popular" elements. The conflict between the two defined political life in the island. Classes were not necessarily wholly associated with one faction or the other, as was the case with the merchants who were members of both factions. However, classes tended to disregard the dichotomous political divide when the interests of the class were at stake. Both "aristocratic" and "popular" merchants, for instance, voted almost in unison on certain financial issues. ${ }^{27}$ Therefore, parallel to the formation of the bipartisanship, classes sought further cohesion in social and political matters. ${ }^{28}$ Against this unstable and contentious climate, political factions and social classes sought to fortify capital and buttress interests at the expense of their rivals. In short, the situation in Majorca was one of partisan politics anchored to a large degree in class consciousness.
The case of the corner statues demonstrates that the merchants subscribed to this type of politics, as they were concerned with asserting ownership, making territorial claims and identifying allies. Moreover, as Joan Domenge i Mesquida suggested, the plan of the Lonja was probably influenced by that of the Tour Maubergeon, the donjon of the Palais de Justice of Poitiers (Guillem Sagrera likely witnessed the contemporary reconstruction of the palace by Guy de Dammartin, the Duke of Berry's architect). ${ }^{29}$ In many respects the Lonja resembles a keep (in addition to its resemblance to a church) with its four corner towers, square plan, overall robustness, and conspicuous crenellations. These fortification elements contribute to the sense of the Lonja being a manifestation of the merchants' effort to secure, fortify, and buttress assets in view of confrontational and tensed politics.

The differentiation or entrenchment strategy of the merchants could be interpreted also as an act of defiance whose target was particularly the King of Aragon and his deputies. Hostility towards the king grew stronger in Majorca during the first decades of the fifteenth century. In 1401, King Martin the Humane even deposed and replaced the elected jurats..$^{30}$ Martin died in 1410 leaving no legitimate descendants. In the ensuing succession struggle, many Mallorcans, especially those belonging to the "popular" party, supported the candidacy of James II, Count of Urgell. When Ferdinand of Antequera was finally elected as a king in 1412, he ordered the island's lieutenant to arrest prominent Mallorcans who, fearing royal prosecutions, planned on leaving the island. ${ }^{31}$ Thus, it is no surprise that none of the corner statues point to the Almudaina - the royal palace and the seat of the King's representatives - despite its importance and adjacency to the Lonja. The royal outposts were purposefully ignored. Interestingly, St. Catherine was known for defying emperor Maxentius who eventually ordered her torture and execution. At the Lonja, her statue is shown trampling a vanquished king under her feet (fig. 7). Moreover, The language of the contract pays lip service to the king by stating that St. Clare should face the Almudaina, but in reality, and perhaps even subversively, it points to the convent of Santa Clara. Still in the contract, the merchant guild dictates that a statue of the Virgin should be placed over one of the two main portals and an angel - the merchants' emblem- over the second. ${ }^{32}$ Once again directions are specified - the statue of the

\footnotetext{
${ }^{25}$ A. ZARAGOZÀ CATALÀN argues that the twisted columns allude to the columns in Solomon's Temple in Inspiración bíblica y presencia de la Antigüedad en el episodio tardogótico valenciano, in S. DAUKSIS ORTOLÁ and F. TABERNER PASTOR (eds.), Historia de la ciudad II: Territorio, sociedad y patrimonio, Valencia, 2002, p. 165-83. See also J. DOMENGE I MESQUIDA, Guillem Sagrera," in M. R. NOBILE and E. GAROFALO (eds.), Gli ultimi indipendenti. Architetti del gotico nel Mediterraneo tra XV e XVI secolo, Palermo, 2007, 73.

${ }^{26}$ A. SANTAMARÍA ARÁNDEZ, El reino de Mallorca en la primera mitad del siglo XV, Palma de Mallorca, 1955; Idem, Mallorca en el siglo XIV, in Anuario de estudios medievales 7, 1970-1971, p. 253-78; P. CATEURA BENNÀSSER, El bipartidismo en la Mallorca de comienzos del siglo XV, Bolletí de la Societat Arqueològica Lulliana 41, 1985, p. 157-70; J. SERRA I BARCELÓ, op. cit. (n. 19).

${ }^{27}$ P. CATEURA BENNÀSSER, op. cit. (n. 26).

${ }^{28}$ Despite their central role in Majorca since the conquest, the caballeros, for example, began to further coordinate their actions by means of the confraternity of Sant Jordi only in the fourtheenth century and especially at the beginning of the fifteenth. C. PONS LLABRÉS, La condición de los caballeros en el reino de Mallorca, Siglos XIII-XV, Universitat de les Illes Balears, 1985.

29 J. DOMENGE I MESQUIDA, op. cit. (n. 25), p. 70-1.

3o A. SANTAMARÍA ARÁNDEZ, op. cit. (n.26), p. 24; J. SERRA I BARCELÓ, op. cit. (n. 19), p. 16-7.

${ }^{31}$ P. CATEURA BENNÀSSER, op. cit. (n. 26), p. 165-6.

${ }^{32}$ Two more angel statues were placed at the center of the Lonja's northeastern and southwestern sides. The merchants appropriated the angel as their emblem in 1409. Both the monumental angel which crowns the Lonja's eastern entrance (fig. 10) and an angel on a plaque commemorating the building of a portico in 1444 on the façade of the Consulado del Mar carry a phylactery that identify them as the "Defender of Trade". Several angels are to be found on the ceiling bosses as well. See T. SABATER op. cit. (n. 6), p. 121; G. ALOMAR ESTEVE, op. cit. (n. 3), p. 118-24. A. JUAN VICENS, La actividad escultórica de Huguet Barxa. Nuevas perspectivas, in Archivo Español de Arte 87, no. 347, 2014, p. 209-26.
} 


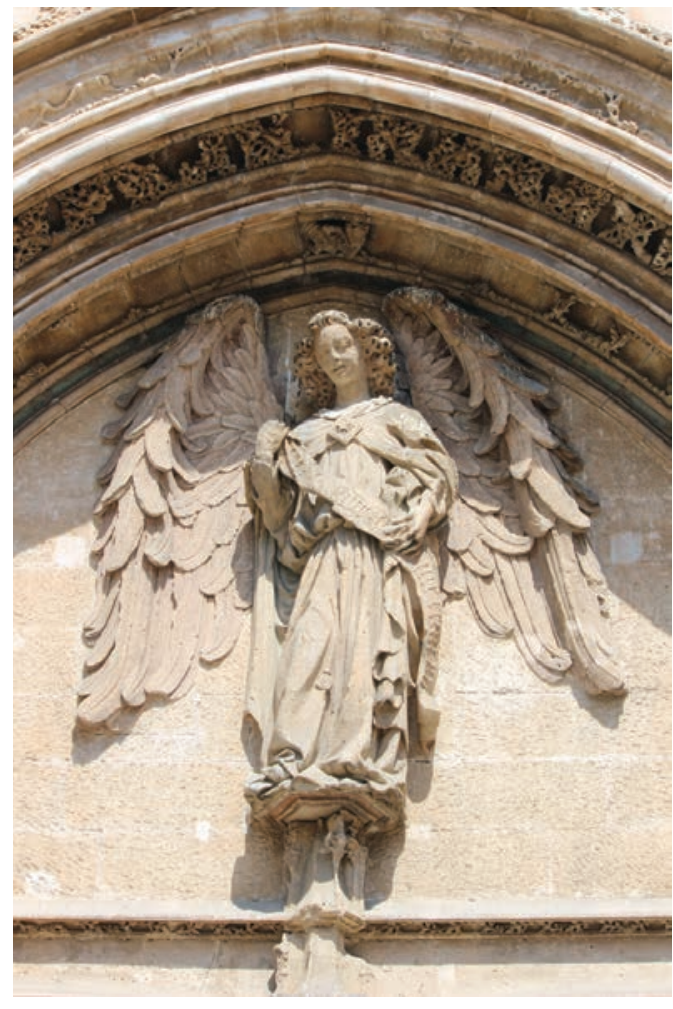

Fig. 13. The tympanum angel above the southeastern entrance, The Lonja of Palma

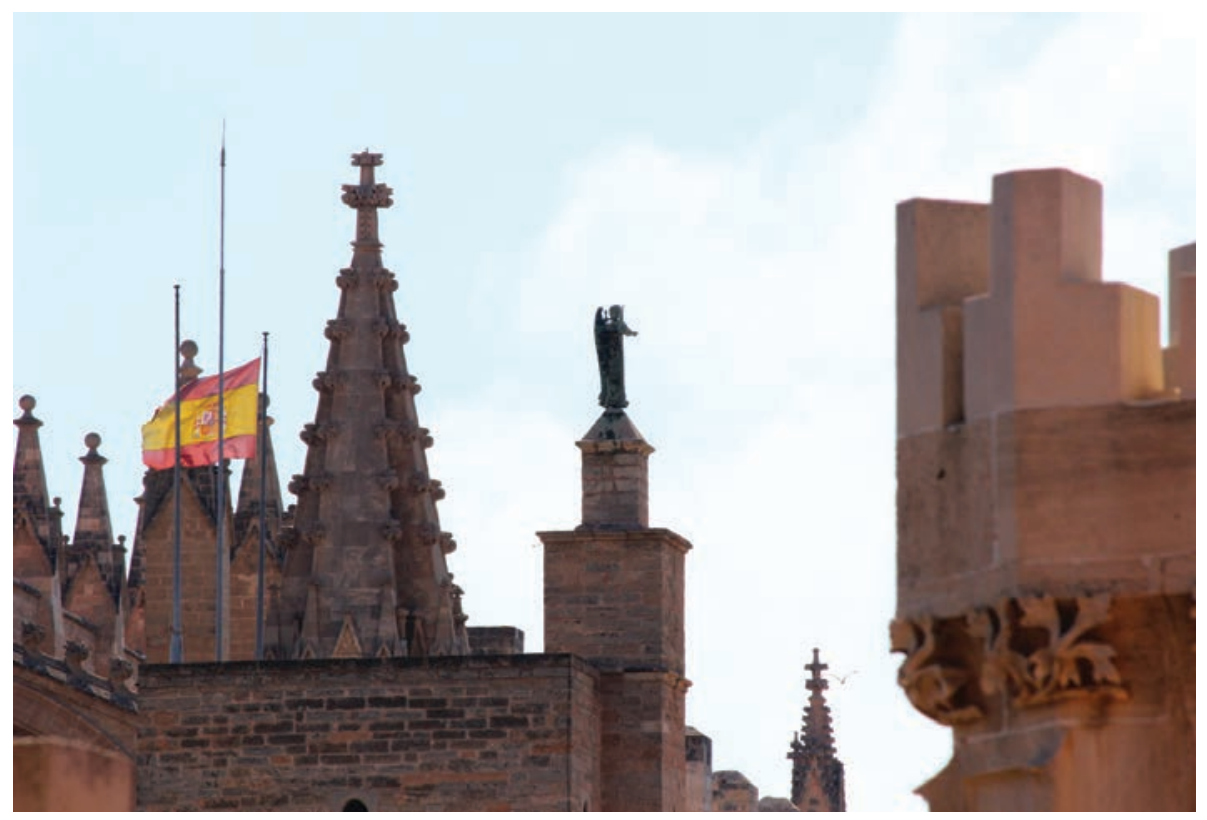

Fig. 14. The Almudaina's Torre del angel and its vane as seen from the rooftop of the Lonja of Palma
Virgin should face the Alm u d a in a . However, the actual portals are reversed.

It is the angel of the merchants rather than the Virgin that faces the Almudaina (fig. 13). The vane that topped the highest tower of the Almudaina may explain this unplanned change of orientation (fig. 14). The vane was in fact a statue of an angel that was one of the most known features of the city of Palma. The vane-angel was the source of the tower's name - la torre del ángel. Due to their height, the tower of the angel together with the cathedral's campanile offered the first view of the city to mariners approaching the port. ${ }^{33}$ The tower of the angel became the symbol of the Almudaina and as result a symbol of royal power. ${ }^{34}$ The post-contract decision to place the "angel of the merchants" on the side

facing the "royal" angel could be read as a mise-en-scène of a duel between the two. The angel, defender of trade and tradesmen, challenges the royal angel over the political dominance of the city. ${ }^{35}$

The tension between Emperor Charles V's description of the Lonja as a church and the modern conception of the merchants as forerunners of secularism is resolved, then, by realizing that the merchants employed such religious imagery as the corner statues not just for religious purposes, but also as symbolical topographical pointers. By doing so the merchants employed cartographic thinking to transform religious iconography into a potent political tool. Majorca was the home of one of the most important and advanced cartographic schools in the Late Middle Ages, and therefore, it was only natural, that the merchants of Palma were aware of the power of maps to make political arguments. ${ }^{36}$

\footnotetext{
33 G. LLOMPART, El angel-veleta de la Almudaina de Mallorca (siglo XIV), in Studia Luliana 15 1971, p. 221-220.

${ }^{34}$ For example, the banner of the city and Kingdom of Majorca featured the angel. See the unnumbered figure between pages 12-13 in B. PONS I FÀBREGUES, La Bandera de la ciudad de Mallorca, Palma de Mallorca, 1907.

35 According to the contract, the three statues of the angels were supposed to be accompanied by the royal coat of arms and the city's coat of arms. There are no traces of these coats of arms which means they were either lost or never realized. If the latter is true then the decision not to place the royal coat of arms next to that of the city might be read as an act of defiance against royal power as well. See D. A. FRAU, op. cit. (n. 7).

${ }^{36}$ In the fifteenth century, the majority of Palma's map makers lived in the area of the Lonja, see G. LLOMPART, Registro de los cartógrafos medievales activos en el puerto de Mallorca, in Anuario de Estudios Medievales 27, 1997, p. 1117-48.
} 